\title{
CRITERIA FOR EXPLOITATION OF WATER RESOURCES: PLANNING AND MANAGEMENT OF IRRIGATION SYSTEMS WITH HIGH EFFICIENCY FOR THE GREEN CITY OF MILAN
}

\author{
MARIA LAURA DEANGELIS \& NICOLA FACOETTI \\ DiSAA, University of Milan, Italy
}

\begin{abstract}
Automated irrigation of parks and gardens has become increasingly common practice thanks to the numerous benefits it brings in terms of improving the quality of urban green areas. Since this practice requires significant volumes of water, a resource that is becoming increasingly scarce and expensive, the design criteria and management for use in the preparation of a project must maximize irrigation efficiency. The City of Milan has given us the task of designing a new irrigation system for the Indro Montanelli park, to replace the existing but obsolete system, in line with the principles of exploitation of water resources, cost of implementation and a simpler management system. Improvement in performance both from an agronomic viewpoint and in terms of appearance, functionality and improved usability by users seem to be the main objectives that the administration wishes to reach in the green areas of the park located in the heart of the city. In this paper, the extent of the green heritage of the city and the ways in which it is currently run are analyzed, then the design and management criteria are explained. In the next phase of the work different management criteria are compared, in order to motivate the design choices made, and an irrigation management model on a municipal scale level is also proposed. The aim is to provide the municipal administration with a preliminary project document which can meet the real needs of the irrigated species in the park through optimal solutions from both a technical and economic viewpoint and in terms of water savings compared to the systems currently existing in the green areas of the city.
\end{abstract}

Keywords: automatic irrigation, water management.

\section{INTRODUCTION}

The green areas of the City of Milan cover a total of about 22 million $\mathrm{m}^{2}$. The city center is home to a number of historic parks, including the Indro Montanelli Park, dating from the second half of the 18th century, the Sempione Park, late $19^{\text {th }}$ century, and Pope John Paul II Park dating from 1934.

The City of Milan has a total of 758 irrigation systems present in public green areas (Table 1).

The remote control works on $48 \%$ of the areas to be irrigated; $48 \%$ are controlled remotely but $90 \%$ of the irrigation plants are managed locally - this means that operators require approximately 60 days of work to start up the plants by operators. The critical element which weighs most on the efficiency of municipal irrigation systems appears to be the total absence of irrigation sensors. Over the years all the rain sensors have been destroyed by continual acts of vandalism.

\section{THE NEW PROJECT}

The layout of the project has been designed with protected areas to safeguard the trees from wetting by the sprinklers which is damaging because the water jet directed against the trunk of the trees can create conditions that favor wood decay, especially where wounds are caused by frequent green area maintenance work, a common problem in historical parks. 
Table 1: Irrigation plants in Milan: structural data and water supply.

\begin{tabular}{|l|l|l|}
\hline Structural data & u.m. & \\
\hline Municipal irrigation systems & $\mathrm{n}$. & 758 \\
\hline Operative systems & $\mathrm{n}$. & 652 \\
\hline Inoperative systems & $\mathrm{n}$. & 23 \\
\hline Obsolete systems & $\mathrm{n}$. & 73 \\
\hline No data & $\mathrm{n}$. & 10 \\
\hline Irrigated area & $\mathrm{m}^{2}$ & $2,429,041.0$ \\
\hline Control & & \\
\hline Remote & $\mathrm{n}$. & 90 \\
\hline Local & $\mathrm{n}$. & 668 \\
\hline Remote control & $\%$ & 11.87 \\
\hline Local control & $\%$ & 88.13 \\
\hline Remote control area & $\%$ & 48.49 \\
\hline Water supply & & \\
\hline Well & $\%$ & 3.56 \\
\hline Aqueduct & $\%$ & 96.44 \\
\hline No data & $\mathrm{n}$. & 27 \\
\hline Power supply & & \\
\hline Battery & $\%$ & 59.97 \\
\hline Electrical power network & $\%$ & 39.88 \\
\hline Solar panels & $\%$ & 0.15 \\
\hline No data & $\mathrm{n}$. & 96 \\
\hline Irrigation season - consumption & & \\
\hline Period & $\mathrm{from}-\mathrm{to}$ & $04 / 01-10 / 31$ \\
\hline Period & $\mathrm{dd}$ & 214 \\
\hline Average water consumption & $\mathrm{mm} / \mathrm{dd}$ & 5.86 \\
\hline & & \\
\hline
\end{tabular}

A census of the tree species in the park was carried out, recording the following data for each tree: location, genus, species, variety, height, trunk diameter measured one meter from the ground, diameter of the crown, estimated and calculated age and health.

This information was used to associate an area not irrigated by the sprinkler jet for each tree. This problem has never been specifically addressed in the literature, although there are some operational standards used mainly to define buffer zones to protect trees from construction activities.

According to "British standard BS 5837:2005 Trees" [1] in relation to construction and recommendations, the root protection area (RPA) can be calculated for a single tree using the following formula:

$$
\operatorname{RPA}\left(\mathrm{m}^{2}\right)=\left(\frac{\text { trunk diameter }(\mathrm{mm}) \text { at } 1.5 \mathrm{~m} \cdot 12}{1000}\right)^{2} \cdot 3.142 .
$$

For multi-trunk specimens, the RPA is: 


$$
\operatorname{RPA}\left(\mathrm{m}^{2}\right)=\left(\frac{\text { diameter of the root zone }(\mathrm{mm}) \cdot 10}{1000}\right)^{2} \cdot 3.142 \text {. }
$$

This means that a buffer zone equal to 10-12 times the trunk diameter should be considered (measured at $1.5 \mathrm{~m}$ from the ground). However, these values allow for very few irrigated areas due to the huge buffer zone to be allocated to each tree, making the existence of good quality turf completely impossible.

For this reason, an empirical formula developed by the European Nurserystock Association [2] was adopted. The document contains important quality standards applied in ornamental arboriculture; in particular, a minimum diameter equal to 3 times the diameter of the stem is considered as a buffer zone.

So, the final formula used to establish the root protection area by the action of the sprinklers is as follows:

$$
\operatorname{RPA}\left(\mathrm{m}^{2}\right)=\left(\frac{\text { trunk diameter }(\mathrm{mm}) @ 1 \mathrm{~m} \cdot 3}{1000}\right)^{2} \cdot 3.142 .
$$

All the trees were first divided into three classes of diameters in a GIS environment and subsequently the formula (3) was applied to obtain the RPA. The results are shown in Table 2.

This method is easy to apply and works well in parks having a substantial density of trees. In addition to protecting the trees and permitting the coexistence of turf and tree species, the application of this method, compared to the original plan, allows direct irrigation only where it is actually needed.

The park comprised approximately $84,700 \mathrm{~m}^{2}$ of green areas, characterized by the presence of trees, shrubs and herbaceous species. In the method applied the irrigated area is equal to $44,965 \mathrm{~m}^{2}$. Comparing the indiscriminate irrigation of all the green areas of the park with the application of the method used for this project, an irrigated area savings of $47 \%$ would be obtained. In any case, the application of this method produces a significant saving of water where significant quantities of trees are present in the green areas.

For this project, 1138 sprinklers have been used, characterized by position, nozzles, different working radii and angles.

First, the .dwg project CAD file was converted into a .dxf swap file. Qgis software was used to turn all the layers into a single shapefile.

An identification number was assigned to each sprinkler, adding information such as the sprinkler type, the radius $(\mathrm{m})$, the arc, the nozzle, the flow rate $\left(\mathrm{m}^{3} / \mathrm{h}\right)$ and the coordinates in the WGS84 reference system.

Furthermore, the file contains all the plant species located in the park. Every single plant is georeferenced. This new shapefile, created with an open-source GIS software, is an essential support from the operational point of view, in particular when used with a single tablet in combination with a sufficiently accurate GPS receiver.

Table 2: Root protection areas applied in the project.

\begin{tabular}{|l|l|}
\hline Trunk diameter range (mm) & RPA $\left(\mathbf{m}^{2}\right)$ \\
\hline $60-1000$ & 28.27 \\
\hline $1001-1999$ & 113.11 \\
\hline $2000-2640$ & 254.50 \\
\hline
\end{tabular}




\section{MANAGEMENT SYSTEM ANALYSIS}

Four different operating criteria were analyzed by performing a water balance in the investigated area using the procedure described in FAO56 paper [3]. The irrigation rate is calculated only if, at the beginning of a generic day $t$, the deficit rate (DR) in the rooted layer is greater than a threshold value $\alpha \cdot \mathrm{RAW}$, thus avoiding stress conditions.

In general, if the water supply is not limited, an $\alpha$ value between 0.7 and 0.9 is adopted which also provides a safety margin to compensate for the inevitable uncertainties in the estimation of the deficit.

In situations of low water availability $\alpha$ values very close to or even greater than one (Deficit irrigation) are set.

In the case of turf, the $\alpha$ value reflects the desired quality of the grass. In general, this value, settable in the most advanced programs, can be modified to improve the quality of the turf in the case of non-limiting water resources. It could also be lowered to obtain a reduction in the turf growth and, therefore, the number of cuts, thanks to forms of controlled stress, but to the detriment of the surrounding microclimate.

Management of the $\alpha$ coefficient would require further experimental investigations in order to raise the intervention threshold to values even greater than one, without having a significant drop in the turf quality and degradation of the surrounding microclimatic conditions; in this regard, the use of cultivars resistant to water stress for re-seeding could be effective.

The use of the $\alpha$ coefficient could be very advantageous for the correct management of stress causes, as an increase of the biomass ratio roots/biomass culms [4] can be obtained. This is mainly due to the lower growth of the culms and to a greater accumulation of carbon in the roots in moist layers underlying dry ones [5]. Many authors have investigated the effects of irrigation frequency, pointing out that if it is too high it induces a shallow root development ([6]-[10]) and increases the development of diseases and weeds [11]. On the other hand, software programming of lower frequency irrigation can improve drought resistance mechanisms, as well as root depth [12]. These elements will be considered in the formulation of criteria for correct programming.

For planning purposes, we chose a value of 0.8 for the $\alpha$ coefficient in line with the literature cited in the bibliography. In the first scenario considered, we analyzed the behavior of the turf without irrigation over a period of ten years. The period considered for the analysis refers to the irrigation season of 214 days $(01 / 04-31 / 10)$ and three different conditions were evaluated using:

1. weather data averaged over 10 years (2005-2015);

2. a year characterized by the minimum number of days for which the following relationship holds: DR $\geq$ RAW (minimum water stress);

3. a year characterized by the maximum number of days in which the following relationship holds: DR $\geq$ RAW (maximum water stress).

Four scenarios were analyzed. In the first one, no irrigation is assumed. In the second case the irrigation management criterion is turn and volume, both constant and independent of weather conditions. This method is currently used in Milan because of the absence of control sensors.

In the third case, the irrigation management criterion is again turn and volume, both constant, but characterized by the interruption of irrigation when a certain threshold value of rain is exceeded. This operation is usually carried out by the rain sensor, but in the case of the Municipality of Milan it is activated in manual mode due to problems of vandalism. 
A value of $3 \mathrm{~mm}$ is set up for the interruption of irrigation and is used in most cases. This criterion has obvious limits since it is extremely difficult to simulate the actual choices adopted by the municipality, because of the subjective evaluation systems used by the operator in deciding whether or not to activate the irrigation system.

In the last case, the water supply is simulated changing both turn and volume; this procedure is applicable using the most advanced forms of irrigation management.

Simulations were run assuming no irrigation and the results show that for the first condition on $74.3 \%$ of irrigation days there is water stress, $33.2 \%$ for the second scenario and $89.7 \%$ for the third case.

The results highlight an evident situation, following what has been found in literature and confirmed by the town engineer about the unfeasibility for the turf to exist in the transition zones without the help of irrigation, with an inevitable decrease of quality. This situation would force municipalities to continual re-seeding or turfing with uncertain outcomes. Therefore, the planning policy for efficiency should be based on irrigation management through water balance.

This opportunity provided by this new irrigation system is made possible using weather stations connected to an automatic control unit which optimizes the use of water and ensures the best conditions for crops. The results obtained for a plant with sprinklers in Montanelli Park are shown in Fig. 1.

The crop is never subject to water stress even if the distributed water is only $301.4 \mathrm{~mm}$, equivalent to $11,789.26 \mathrm{~m}^{3}$ of water, which is $57.98 \%$ less compared to automatic irrigation connected to a rain sensor and $71.72 \%$ less than the case with fixed turn and volume.

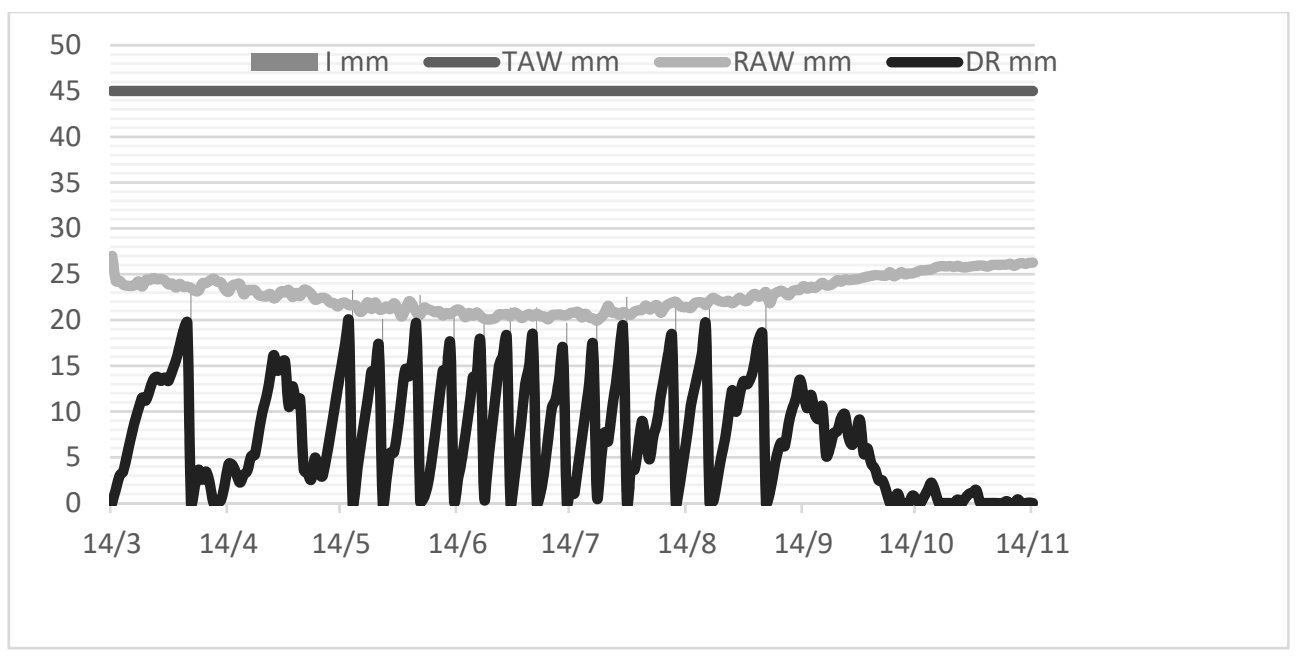

Figure 1: TAW (total available water, $\mathrm{mm}$ ), RAW (readily available water, $\mathrm{mm}$ ) and DR (water deficit, $\mathrm{mm}$ ) applying simulations to weather data averaged over 10 years with automatic irrigation controlled by a weather station. 


\section{CONCLUSIONS}

In the words of a famous statement, "Efficiency depends more on the quality of management than the quality of the facilities" [13].

This affirmation is confirmed by the calculations of the hydrological balance for the crops analyzed, even if, unlike other cases, in this project an optimization criterion has been applied to an unprecedented irrigated area. In particular, the RPA method has been applied, obtaining a water saving that, in the worst case, is $29.26 \%$ if compared to the irrigation volumes originally planned for the park determined using the design criteria found in the old project of 2002 adhering to the instructions of the manufacturers.

In addition to considerations of water and economic saving, from a technical viewpoint the project adopted innovative design solutions aimed at optimizing the dimensioning of pipelines and components. Significant advantages both from the viewpoint of uniformity of distribution and economic savings on the costs of installing and managing the plant will be obtained. The most effective solutions for saving water have been implemented through the choice of hardware devices and innovative software capable of managing the system in automatic mode through variable turn and volume criteria.

This choice, together with the RPA method adopted for the project, has resulted in a total water saving of $70.28 \%$ if compared with fixed turn and volume interrupted by rain and of $80 \%$ if related to the case with just fixed turn and volume currently adopted by the municipality. These values correspond respectively to an annual water saving for irrigation of the Montanelli Park equal to 56,019.7 $\mathrm{m}^{3}$ of water in the first case and of $63,767.4 \mathrm{~m}^{3}$ in the second.

\section{REFERENCES}

[1] British standard BS 5837, Trees in relation to construction-Recommendations, 2005.

[2] European Nurserystock Association, European Technical \& Quality Standards for Nurserystock, p. 34, 2010.

[3] Allen, R., et al., Crop evapotranspiration. Guidelines for computing crop water requirements. FAO, Irrigation and Drainage Paper 56, 2008.

[4] Carrow, R.N., Krum, J.M., Flitcroft, I. \& Cline, V., Precision turfgrass management: challenges and field applications for mapping turfgrass soil and stress. Precision Agric., 2009.

[5] Huang, B. \& Fu, J., Photosynthesis, respiration, and carbon allocation of two coolseason perennial grasses in response to surface soil drying. Plant Soil, 227, pp. 17-26, 2000.

[6] Hagan, R.M., Watering lawns and turf and otherwise caring for them. Water: The Yearbook of Agriculture, ed. A. Stefferud, U.S. Gov. Print. Office: Washington, DC, pp. 462-467, 1955.

[7] Shearman., R.C. \& Beard, J.B., Environmental and cultural preconditioning effects on the water use rate of Agrostis palustris Huds., cultivar Penncross. Crop Science, 13(4), pp. 424-427, 1973.

[8] Qian, Y.L. \& Fry, J.D., Irrigation frequency affects Zoysia grass rooting and plant water status. HortSci., 31, pp. 234-237, 1996.

[9] Davies, W.J. \& Zhang., J., Root signals and the regulation of plant growth and development in drying soil. Annual Review of Plant Physiology and Molecular Biology, 42, pp. 55-76, 1991.

[10] Hull, R.J., Managing turf for maximum root growth: are you making your job more difficult by not getting to the roots of many turf management problems. Turfgrass Trends, 5(2), pp. 1-9, 1996. 
[11] McDonald, D.K., Ecologically Sound Lawn Care for the Pacific Northwest: Findings from the Scientific Literature and Recommendation from Turf Professionals, Seattle Public Utilities, Community Services Division, Resource Conservation Section: Seattle, WA, 1999.

[12] Youngner, V.B., Physiology of water use and water stress. Turfgrass Water Conservation, Publ. 21405, University of California, pp. 37-43, 1985.

[13] Keller, J. \& Bliesner, R.D., Sprinkle and Trickle Irrigation, AVI Book: New York, 1990. 